\title{
ICU staffing models and patient outcomes
}

\author{
Nobuaki Shime
}

\begin{abstract}
The study by Ogura et al. investigated the association between the structures of intensive care units (ICUs) affecting patient outcomes. A major limitation of this study is that the types of ICUs had not clearly been defined, and the provided definition had been made subjectively. Making an additional questionnaire or site-visits to completely define the types and to clarify the time-coverage is suggested. It would also be worthwhile to analyze whether the existence and density of "certified intensivists" and their involvement contribute to the outcome to determine whether physician quality affects critically ill patient care.
\end{abstract}

Keywords: Intensive care unit, Structure, Closed, Intensivist

To the Editor,

I read with considerable interest the article published in a recent issue of Journal of Intensive Care by Ogura and colleagues [1], who have shown a significant association between the type of ICUs and outcomes of patients diagnosed with sepsis. They made a post hoc analysis using fairly large-scaled registry data of $>2400$ cases from the Japan Septic Disseminated Intravascular Coagulation study and found that the length of intensive care unit (ICU) stay was shorter and mortality was lower for patients managed in "closed" ICUs. The study should be admired for shedding light on how the structure of ICUs affect patient outcomes, which is scarcely investigated outside North America [2-4].

As the authors described, however, a major limitation of their study is associated with its definition of types of ICUs, which was not clearly defined, and with the provided definition having been made subjectively. Given the nature of the study (post hoc analysis) and with merely 35 open- or closed-ICUs participating, it would not be impossible to redefine the structures, possibly by making an additional questionnaire or site-visits. By doing that, not only the consultation density but also time-coverage $(24 \mathrm{~h}$ a day or not) could be evaluated [2]. This might also help to ensure non-exclusion of the data $(\sim 500$ cases were excluded in their study) when ICUs are not clearly classified as closed or open, making the analysis more robust.

Ideally, fundamental definitions regarding ICU structures should be established by any professional intensive care society, not by individual researchers, for common understanding. This is a prerequisite for the professional academic society for further advancement.

In addition, the authors defined the type of ICUs by the degree of consultation (none or elective vs. mandatory) to intensivists. It is important to describe and assess who the "intensivists" were. To date, the number of certified intensivists by the Japanese Society of Intensive Care Medicine reaches barely $\sim 1500$. It would be worthwhile to analyze whether the existence and density of "certified intensivists" and their involvement in patient care, including sepsis management, really contributes to significant outcomes [3]. Furthermore, it would be of great interest to see whether the quality of physicians could affect critically-ill patient care [4].

I believe that clarification of these issues would be helpful for better understanding of the benefit of ICU models in sepsis management.

Correspondence: shime@koto.kpu-m.ac.jp

Department of Emergency and Critical Care Medicine, Graduate School of Biomedical and Health Sciences, Hiroshima University, 1-2-3 Kasumi, Minami-ku, Hiroshima 734-8551, Japan

(c) The Author(s). 2019 Open Access This article is distributed under the terms of the Creative Commons Attribution 4.0 International License (http://creativecommons.org/licenses/by/4.0/), which permits unrestricted use, distribution, and reproduction in any medium, provided you give appropriate credit to the original author(s) and the source, provide a link to the Creative Commons license, and indicate if changes were made. The Creative Commons Public Domain Dedication waiver (http://creativecommons.org/publicdomain/zero/1.0/) applies to the data made available in this article, unless otherwise stated. 


\section{Abbreviation}

ICU: Intensive care unit

\section{Acknowledgements}

The author thanks Edanz Group (www.edanzediting.com/ac) for editing a draft of this manuscript.

\section{Funding}

This work was supported by KAKENHI Grants from the Japan Society for the Promotion of Science (JSPS) (numbers JP 17K11573).

\section{Availability of data and materials}

Data sharing not applicable to this article as no datasets were generated or analyzed during the current study.

\section{Authors' contributions}

NS solely contributed to this work. The author read and approved the final manuscript.

\section{Ethics approval and consent to participate}

Not applicable.

\section{Consent for publication}

Not applicable.

\section{Competing interests}

The authors declare that they have no competing interests.

\section{Publisher's Note}

Springer Nature remains neutral with regard to jurisdictional claims in published maps and institutional affiliations.

Received: 27 March 2019 Accepted: 9 April 2019

Published online: 24 April 2019

\section{References}

1. Ogura T, Nakamura Y, Takahashi K, Nishida K, Kobashi D, Matsui S. Treatment of patients with sepsis in a closed intensive care unit is associated with improved survival: a nationwide observational study in Japan. J Intensive Care. 2018; Sep 3;6:57.

2. Nishisaki A, Pines JM, Lin R, Helfaer MA, Berg RA, Tenhave T, et al. The impact of 24-hr, in-hospital pediatric critical care attending physician presence on process of care and patient outcomes. Crit Care Med. 2012;40:2190-5.

3. Petitti D, Bennett V, Chao Hu CK. Association of changes in the use of board-certified critical care intensivists with mortality outcomes for trauma patients at a well-established level I urban trauma center. J Trauma Manag Outcomes. 2012(Mar 6;6):3.

4. Kerlin MP, Epstein A, Kahn JM, Iwashyna TJ, Asch DA, Harhay MO, et al. Physician-level variation in outcomes of mechanically ventilated patients. Ann Am Thorac Soc. 2018:15:371-9.

Ready to submit your research? Choose BMC and benefit from:

- fast, convenient online submission

- thorough peer review by experienced researchers in your field

- rapid publication on acceptance

- support for research data, including large and complex data types

- gold Open Access which fosters wider collaboration and increased citations

- maximum visibility for your research: over $100 \mathrm{M}$ website views per year

At $\mathrm{BMC}$, research is always in progress.

Learn more biomedcentral.com/submissions 